\title{
Impact of gamma radiations on wheat (Triticum aestivum L.) varieties (Batoor and Janbaz)
}

\author{
Sajjad Ahmed ${ }^{1}$, Wisal Muhammad Khan ${ }^{1 *}$, Muhammad Saleem Khan ${ }^{1}$, \\ Naveed Akhtar ${ }^{1}$, Nosheen $\mathrm{Umar}^{2}$, Sajjad Ali $^{3}$, Saddam Hussain ${ }^{1}$ and \\ Syed Sadaqat Shah ${ }^{1}$
}

1. Department of Botany, Islamia College Peshawar-Pakistan

2. Department of Botany, University of Peshawar-Pakistan

3. Department of Botany, Bacha Khan University, Charsadda-Pakistan

*Corresponding author's email: wisalmadani@ hotmail.com

Citation

Sajjad Ahmed, Wisal Muhammad Khan, Muhammad Saleem Khan, Naveed Akhtar, Nosheen Umar, Sajjad Ali, Saddam Hussain and Syed Sadaqat Shah. Impact of gamma radiations on wheat (Triticum aestivum L.) varieties (Batoor and Janbaz). Pure and Applied Biology. Vol. 6, Issue 1, pp218-225.

http://dx.doi.org/10.19045/bspab.2017.60017

Received: 04/11/2016

Revised: $25 / 01 / 2017$

Accepted: 06/02/2017

Online First: 11/02/2017

\section{Abstract}

The present investigation was carried out to evaluate the effect of different doses of gamma rays (15, 25, 35 and $45 \mathrm{Krad}$ ) on various morphological and biochemical parameters of two wheat varieties (Batoor and Janbaz). A comparison of the results of different doses with control showed that gamma irradiations significantly affected various parameters. Days to germination were non-significantly delayed in Batoor while significantly decreased at $45 \mathrm{Krad}$ in Janbaz. Germination percentage decreased significantly at 15 Krad in both varieties. Days to spike initiation significantly decreased at $45 \mathrm{Krad}$ in Batoor but increased significantly at $45 \mathrm{Krad}$ in Janbaz variety. Days to spike maturation were increased significantly at 45 Krad in both varieties. Plant height increased significantly at $15 \mathrm{Krad}$ but decreased expressively at 25 Krad and $35 \mathrm{Krad}$ in Batoor. In Janbaz plant height increased significantly at $45 \mathrm{Krad}$ but decreased at 35 Krad. Number of nodes/plant decreased significantly at various doses in Batoor. While in Janbaz number of nodes/plant increased significantly at $15 \mathrm{Krad}$. Gamma radiation significantly increased number of fertile tillers/plant at $15 \mathrm{Krad}$ in Batoor and at $45 \mathrm{Krad}$ in Janbaz. Number of spikes/plant increased significantly at $15 \mathrm{Krad}$ in Batoor and at $45 \mathrm{Krad}$ in Janbaz. Number of spikelets/spike increased at 15 Krad in Batoor while a decreasing trend was seen in Janbaz with increasing doses. Spike length was nonsignificantly affected by gamma radiation in Batoor variety. However spike length was significantly increased at $45 \mathrm{Krad}$ in Janbaz. Number of grains/spike increased significantly at $15 \mathrm{Krad}$ in Batoor but decreased significantly at higher doses in both varieties. 1000 grain weight significantly increased at 45 $\mathrm{Krad}$ in Batoor and at $15 \mathrm{Krad}$ and $25 \mathrm{Krad}$ in Janbaz. Biochemical analysis revealed that gamma irradiation decreased the ash contents significantly at all the doses in both varieties. Moisture contents decreased significantly in Batoor through gamma irradiation except at $45 \mathrm{Krad}$ which showed nonsignificant effect. However, in Janbaz moisture contents increased significantly at $25 \mathrm{Krad}$. Proteins contents were non-significantly decreased in Batoor, while in Janbaz, proteins contents decreased significantly at $35 \mathrm{Krad}$.

Keywords: Gamma irradiation; Morphology; Biochemical; Batoor; Janbaz 


\section{Introduction}

Triticum aestivum is a cultivated wheat species, also known as common wheat or bread wheat and is a member of family Poaceae. Wheat is the major source of food in Pakistan. Pakistan ranks 6th in terms of wheat production, 8th in terms of area but 59th in terms of yield. It adds $12.5 \%$ to the value added in agriculture and $2.9 \%$ to GDP [1]. Wheat is nutritious food which provides proteins, minerals, B-group vitamins and dietary fibers more in quantity than other cereal crop and help in preparation of different types of foods. In general, $70 \%$ carbohydrates, $12 \%$ water, $2 \%$ fat, $12 \%$ protein, $1.8 \%$ minerals and $2.2 \%$ crude fiber are found in the wheat grain kernel. The history of wheat (Triticum aestivum L.) improvement by acclimatization, selection and hybridization dates back to the remote past. Nowadays, mutation induction has become an established tool in plant breeding to supplement existing germplasm and to improve cultivars in definite traits [2]. Plants created using mutagenesis are known as mutagenic plants or mutagenic seeds. Mutation breeding has made an official release of over 2700 newly developed crop cultivars in about 170 species [3]. Most of the mutant varieties (64\%) are developed using physical mutagens such as Gamma rays [4]. [5] obtained three high grain yielding and early maturing mutants by treating seeds of Brassica juncea L.cv.S-9 with the combine effect of gamma rays and chemical mutagen i.e., Ethyl methane sulphonate (EMS). [6] developed a new oil seed Brassica napus L.cv ABASIN-95 by induced mutation using gamma rays. [7] Studied the effect of higher doses (30 and 35 Krad) of gamma irradiation on different wheat varieties which created some abnormalities in plant for example, a tiller having two ears attached with each and/or prevalence of sterile ears etc.

\section{Materials and methods}

The M2 seeds of two wheat varieties i.e. Batoor and Janbaz were selected for the research project. These seeds were obtained from M1 plants in 2013-14. Gamma irradiation used was generated from the Cobalt-60 source, at Nuclear Institute for Food and Agriculture (NIFA) Peshawar, Pakistan. Wheat seeds (M0) were irradiated with $15,25,35$ and $45 \mathrm{Krad}$ while nonirradiated seeds of each variety were kept as control. An experiment was executed in 2013-2014; M0 plants resulted in M1 seeds which were subjected to experiment in the present study. This study aimed to evaluate the effect of gamma rays in M2 generation.

\section{Field experiment}

A field experiment was carried out in botanical garden, Department of Botany, Islamia College Peshawar, during 20142015. M2 Seeds of each dose were sown on 24 November 2014 in pots; all pots were equally spaced with equal soil contents in each pot. The experimental design was completely random with each dose having 5 replicates. Equal numbers of seeds were sown in all pots.

\section{Parameters}

The parameters i.e., days to germination, germination percentage, days to spike initiation, days to spike maturation, plant height, number of nodes per plant, number of fertile tillers per plant, number of spikes per plant, number of spikelets per spike, spike length, grains per spike, 1000 grain weight, ash percentage, moisture percentage and proteins percentage were studied during this experiment.

\section{Statistical analysis}

Experimental data was statistically analyzed for the Analysis of variation (ANOVA) and least significant difference (LSD) at $\alpha=0.05$ using Statistics 10.0 software. 


\section{Proximate analysis}

Proximate analysis of seeds was carried out at Nuclear Institute for Food and Agriculture (NIFA), Peshawar, Pakistan.

\section{Results and discussion}

Gamma irradiation, being known for its mutagenic effect also showed pronounced effect on M2 generation of wheat varieties. Both varieties responded to gamma rays in M2 generation. However, the response was non-conventional; following results explore the findings of present investigation.

\section{Days to germination}

It is noticeable from Table 1 that days to germination were non-significantly affected by gamma irradiation in Batoor while in Janbaz, days to germination increased from control (9 days) at 25 and $35 \mathrm{Krad}$ (11 days in both) and decreased significantly at 45 Krad (7 days). An early germination was obtained in Janbaz at $45 \mathrm{Krad}$ as compared to control. Similar results were observed by [8], [9] in Zea mays L. and [7] in Triticum aestivum $\mathrm{L}$.

\section{Germination percentage}

Table 1 show that the lowest germination percentage was recorded at $15 \mathrm{Krad}$ in Batoor and Janbaz (84\% and 74\%) as compared to control (90\% in both). Germination percentage was nonsignificantly affected at $45 \mathrm{Krad}$ in both varieties as compared to control [10] as well observed decrease in germination percentage at radiation doses. [11] find that germination percentage decrease at higher irradiation doses. These results also confirm the finding of [12]. Similarly, [13, 14] obtained low germination percentage at irradiation doses.

\section{Plant height $(\mathbf{c m})$}

Table 1 show that in M2 generation of Batoor verity, the highest height was obtained at $15 \mathrm{Krad}(67.6 \mathrm{~cm})$ followed by $45 \mathrm{Krad}(66.2 \mathrm{~cm})$ as compared to control $(61.5 \mathrm{~cm})$. [15] observed the same trend. These results are in agreement with the finding of [16]. In Janbaz, plant height decreased with higher doses of irradiation i.e., $15 \mathrm{Krad}(70.1 \mathrm{~cm}), 25 \mathrm{Krad}(67.5 \mathrm{~cm})$, and $35 \mathrm{Krad}(63.4 \mathrm{~cm})$. The highest height was obtained at $45 \operatorname{Krad}(72.5 \mathrm{~cm})$ as compared to control $(70.6 \mathrm{~cm})$. [14, 17] have already shown that irradiation doses decrease plant height.

\section{Days to spike initiation}

Table 1 shows that in Batoor, an early initiation at $45 \mathrm{Krad}$ (109 days) was observed as compared to control (112 days). [17] likewise observed an early heading in wheat mutants. Janbaz showed a slight delay in days taken to initiation of spike with increasing radiation i.e., at $35 \mathrm{Krad}$ (111 days), and $45 \mathrm{Krad}$ (112 days) as compared to control (109 days). [7] observed the same trend. [18] observed that increasing irradiation doses delay initiation. These results also confirm the finding of [3].

\section{Days to spike maturation}

In Batoor, as shown in Table 1, days to spike maturation were varying with radiation doses such as $25 \mathrm{Krad}$ (149 days), $35 \mathrm{Krad}$ (154 days) and $45 \mathrm{Krad}$ (157 days) as compared to control (152 days). Similarly in Janbaz, the data showed that at $25 \mathrm{Krad}$ (152 days) and $45 \mathrm{Krad}$ (155 days) days were taken to maturation as compared to control (152 days). These results confirm the finding of [19]. An early maturity was observed at $25 \mathrm{Krad}$ in both varieties as compared to control which confirm the finding of [20]. Higher irradiation doses of $45 \mathrm{Krad}$ delayed spike maturation in both verities. 
Table 1. Effect of gamma irradiation on different parameters of wheat verities (Batoor and Janbaz)

\begin{tabular}{|c|c|c|c|c|c|c|c|c|c|c|}
\hline \multirow[t]{2}{*}{$\begin{array}{l}\text { Radiation } \\
\text { Doses } \\
\end{array}$} & \multicolumn{2}{|c|}{$\begin{array}{ll}\begin{array}{l}\text { Days } \\
\text { germination }\end{array} & \text { to } \\
\end{array}$} & \multicolumn{2}{|c|}{ Germination \% } & \multicolumn{2}{|c|}{$\begin{array}{l}\text { Days to spike } \\
\text { initiation }\end{array}$} & \multicolumn{2}{|c|}{$\begin{array}{l}\text { Days to spike } \\
\text { maturation }\end{array}$} & \multicolumn{2}{|c|}{$\begin{array}{l}\text { Plant height in } \\
\text { cm }\end{array}$} \\
\hline & Batoor & Janbaz & Batoor & Janbaz & Batoor & Janbaz & Batoor & Janbaz & Batoor & Janbaz \\
\hline Control & $9 \mathrm{a}$ & $9 \mathrm{~b}$ & $95 \% \mathrm{a}$ & $90 \%$ a & $112 \mathrm{a}$ & $109 \mathrm{~b}$ & $152 \mathrm{bc}$ & $153 \mathrm{ab}$ & $1.5 \mathrm{~b}$ & $0.6 \mathrm{~b}$ \\
\hline $15 \mathrm{Krad}$ & $10 \mathrm{a}$ & $10 a b$ & $84 \% \mathrm{c}$ & $74 \% \mathrm{c}$ & $110 \mathrm{bc}$ & $110 a b$ & $151 \mathrm{~cd}$ & $152 \mathrm{~b}$ & $7.6 \mathrm{a}$ & $0.1 \mathrm{~b}$ \\
\hline $25 \mathrm{Krad}$ & $10 \mathrm{a}$ & $11 \mathrm{a}$ & $89 \%$ b & $87 \%$ ab & $111 \mathrm{ab}$ & $110 \mathrm{ab}$ & $149 \mathrm{~d}$ & $152 \mathrm{~b}$ & $61.7 \mathrm{~b}$ & $67.5 \mathrm{c}$ \\
\hline $35 \mathrm{Krad}$ & $10 \mathrm{a}$ & $11 \mathrm{a}$ & $91 \% \mathrm{~b}$ & $80 \%$ bc & $111 \mathrm{ab}$ & $111 \mathrm{ab}$ & $154 \mathrm{~b}$ & $153 \mathrm{ab}$ & $61.5 \mathrm{~b}$ & $63.4 \mathrm{~d}$ \\
\hline $45 \mathrm{Krad}$ & $10 \mathrm{a}$ & $7 \mathrm{c}$ & $95 \%$ a & $90 \%$ a & $109 \mathrm{c}$ & $112 \mathrm{a}$ & $157 \mathrm{a}$ & $155 \mathrm{a}$ & $66.2 \mathrm{a}$ & $72.5 \mathrm{a}$ \\
\hline LSD $\alpha=0.05$ & 1.6158 & 1.2516 & 2.5032 & 7.0554 & 1.9568 & 2.2076 & 2.5377 & 2.2851 & 2.2719 & 1.7675 \\
\hline
\end{tabular}

Data are represented as Mean $(\mathrm{n}=05)$. Means followed by different letter within the column are significantly different $(\mathrm{P}<0.05)$. (ANOVA followed by Tukey LSD test)

\section{Number of nodes/plant}

Data in Table 2 show that in Batoor, the number of nodes/plant decreased significantly with maximum decrease at 45 Krad (5.9 nodes/plant) as compared to control (6.46 nodes/plant). [21] also observed a decreasing tendency in the number of nodes/plant with increasing radiation doses. In Janbaz, the number of nodes/plant improved significantly at 15 Krad (5.93 nodes/plant) as compared to control (4.43 nodes/plant). The number of nodes/plant decreased at higher doses i.e., $35 \mathrm{Krad}$ (4.01 nodes/plant) and $45 \mathrm{Krad}(4$ nodes/plant) in Janbaz.

\section{Number of fertile tillers/plant}

Table 2 shows that in Batoor, the highest number of tillers/plant was obtained at 15 $\mathrm{Krad}$ (4.18 tillers/plant) as compared to control (3.08 tillers/plant). Lowest number of tillers was recorded at $45 \mathrm{Krad}(3.05$ tiller/plant). In Janbaz, the highest number of tillers was obtained at $45 \mathrm{Krad}(8$ tillers/plant) as compared to control (3.18 tillers/plant). [14] observed the stimulatory effect of all the doses of gamma rays on the number of fertile tillers/plant. Similar results were observed by [15].

\section{Number of spikes/plant}

Data in Table 2 shows that in Batoor, the trait was improved at $15 \mathrm{Krad}(4.14$ spikes/plant) but inhibited significantly at 45 Krad (3.05 spikes/plant) as compared to control (3.06 spikes/plant). Similarly, [15] observed an improvement in the number of spikes/plant at $15 \mathrm{Krad}$. In Janbaz, the efficient dose was $45 \mathrm{Krad}$ (8 spikes/plant) as compared to control (3.18 spikes/plant). [13] obtained mutants that produce higher number of spikes/plant through irradiation doses. [19] already concluded that gamma irradiation up to $30 \mathrm{Krad}$ has little or no Inhibitory effect on number of spikes/plant. [22] also observed variation in number of spikes/plant at different radiation doses.

\section{Number of spikelets/spike}

Table 2 indicate that in Batoor, radiation doses increased number of spikelets/spike with maximum at 15 Krad (55.12 spikelets/spike) as compared to control (47.38 spikelets/spike). However in Janbaz, number of spikelets/spike decreased significantly at $15 \quad \mathrm{Krad} \quad(55.55$ spikelets/spike) as compared to control (63.02 spikelets/spike). Number of spikelets/spike decreased at all doses in Janbaz. Janbaz variety shows co-linearity with the studies of various workers including $[15,19,23]$ and in which they observed significant decrease of spikelet number in nearly all the radiation doses.

Denotation: $\mathrm{B}=$ Batoor $\mathrm{J}=\mathrm{J}$ anbaz

\section{Spike length (cm)}

In Batoor, as shown in Table 2, gamma irradiation showed non-significant effect on spike length. In Janbaz variety an improvement in spike length with increasing radiation has been noticed with maximum 
significance at $45 \mathrm{Krad}(10.60 \mathrm{~cm})$ in comparison with control $(8.69 \mathrm{~cm})$. [20] also observed variation in this trait at different doses. These results are in agreement with the findings of [22]. [19] also observed variation in spike length at different doses. However, [23] observed that gamma rays decreased the average spike length with respect to the control.

Table 2. Effect of gamma irradiation on different parameters of wheat verities (Batoor and Janbaz)

\begin{tabular}{|l|l|l|l|l|l|l|l|l|}
\hline $\begin{array}{l}\text { Radiation } \\
\text { Doses }\end{array}$ & \multicolumn{2}{l|l}{$\begin{array}{l}\text { Number of } \\
\text { nodes/plant }\end{array}$} & $\begin{array}{l}\text { Number of fertile } \\
\text { tillers/plant }\end{array}$ & \multicolumn{2}{l|}{$\begin{array}{l}\text { Number of } \\
\text { spikelets/spike }\end{array}$} & \multicolumn{2}{l|}{$\begin{array}{l}\text { Spike length in } \\
\text { cm }\end{array}$} \\
\hline & Batoor & Janbaz & Batoor & Janbaz & Batoor & Janbaz & Batoor & Janbaz \\
\hline Control & $6.46 \mathrm{a}$ & $4.43 \mathrm{c}$ & $3.08 \mathrm{c}$ & $3.18 \mathrm{~b}$ & $17.70 \mathrm{~cd}$ & $21.15 \mathrm{a}$ & $9.13 \mathrm{a}$ & $8.69 \mathrm{c}$ \\
\hline $15 \mathrm{Krad}$ & $6.15 \mathrm{ab}$ & $5.93 \mathrm{a}$ & $4.18 \mathrm{a}$ & $3.29 \mathrm{~b}$ & $21.33 \mathrm{a}$ & $19.18 \mathrm{~b}$ & $9.18 \mathrm{a}$ & $9.69 \mathrm{~b}$ \\
\hline $25 \mathrm{Krad}$ & $5.95 \mathrm{~b}$ & $5.06 \mathrm{~b}$ & $3.21 \mathrm{c}$ & $3.10 \mathrm{~b}$ & $19.80 \mathrm{~b}$ & $15.25 \mathrm{c}$ & $8.52 \mathrm{a}$ & $9.03 \mathrm{c}$ \\
\hline $35 \mathrm{Krad}$ & $6.21 \mathrm{ab}$ & $4.0 \mathrm{c}$ & $3.54 \mathrm{~b}$ & $3.47 \mathrm{~b}$ & $18.45 \mathrm{c}$ & $16.02 \mathrm{c}$ & $8.58 \mathrm{a}$ & $9.00 \mathrm{c}$ \\
\hline $45 \mathrm{Krad}$ & $5.9 \mathrm{~b}$ & $4 \mathrm{c}$ & $3.05 \mathrm{c}$ & $8 \mathrm{a}$ & $17.30 \mathrm{~d}$ & $14.10 \mathrm{~d}$ & $9.53 \mathrm{a}$ & $10.60 \mathrm{a}$ \\
\hline $\mathrm{LSD} \alpha=0.05$ & 0.5086 & 0.6009 & 0.2388 & 0.5325 & 0.8797 & 0.9598 & 0.9585 & 0.3681 \\
\hline
\end{tabular}

Data are represented as Mean $(n=05)$. Means followed by different letter within the column are significantly different $(\mathrm{P}<0.05)$. (ANOVA followed by Tukey LSD test)

\section{Number of grains/spike}

Table 3 shows that in Batoor as compared to control (35 grains/spike) the number of grains increased significantly at $15 \mathrm{Krad}(42$ grains/spike) but decreased significantly in $45 \mathrm{Krad}$ (26 grains/spike). While in Janbaz number of grains decreased at highest dose of $45 \mathrm{Krad}$ (19 grains/spike) as compared to control (38.71 grains/spike). Higher irradiation doses decreased grain yield/spike in both varieties. The present findings are in agreement with the studies of $[15,19,23]$ and who observed a regular decrease in this trait with the increasing intensity of gamma radiations.

Ash contents (\%)

As shown in Table 3 irradiation doses significantly decreased ash contents (\%) in Batoor; maximum mean value was for control (1.67\%). Similarly in Janbaz, ash contents (\%) decreased at $15 \mathrm{Krad}(1.13 \%)$, $25 \operatorname{Krad}(1.17 \%), 35 \operatorname{Krad}(1.35 \%)$, and 45 Krad (1.17\%) as compared to control (1.37\%). [24] observed a decrease in ash contents $(\%)$ due to irradiation doses in
Pigeon pea. [25] reported a decrease in ash content $(\%)$ of velvet bean seed

Moisture contents (\%)

In Batoor, as shown in Table 3, highest mean value for moisture contents (\%) was obtained in control $(0.50 \%)$ while a significant decrease was observed at 35 $\operatorname{Krad}(0.28 \%)$. [26] also observed a decrease in moisture contents (\%) with higher doses. In Janbaz a significant increase in moisture contents was obtained at $25 \mathrm{Krad}(0.68 \%)$ as compared to control (0.35\%). [24] observed the same trend.

\section{Proteins contents (\%)}

Data in Table 3 shows that in Batoor, highest mean value for proteins was obtained at $15 \mathrm{Krad}(13.16 \%)$ followed by control (13.01\%). In Janbaz, mean value for proteins contents was maximum in control $(13.97 \%)$ and decreased at $35 \mathrm{Krad}$ $(13.16 \%)$. This decrease could be due to partial nitrogen destruction at different doses. [27] also observed a decrease in proteins content at higher irradiation doses (Table 3). 
Table 3. Effect of gamma irradiation on different parameters of wheat verities (Batoor and Janbaz)

\begin{tabular}{|c|c|c|c|c|c|c|c|c|c|c|}
\hline \multirow[t]{2}{*}{$\begin{array}{l}\text { Radiation } \\
\text { Doses }\end{array}$} & \multicolumn{2}{|c|}{$\begin{array}{l}\text { Number of } \\
\text { grains/spike }\end{array}$} & \multicolumn{2}{|c|}{$\begin{array}{l}1000 \text { grains } \\
\text { weight }(\mathrm{g})\end{array}$} & \multicolumn{2}{|l|}{ Ash \% } & \multicolumn{2}{|c|}{ Moisture \% } & \multicolumn{2}{|c|}{ Proteins \% } \\
\hline & Batoor & Janbaz & Batoor & Janbaz & Batoor & Janbaz & Batoor & Janbaz & Batoor & Janbaz \\
\hline Control & $35 c$ & $38.71 \mathrm{a}$ & $32.1 \mathrm{c}$ & $34.4 \mathrm{~b}$ & $1.67 \% \mathrm{a}$ & $1.37 \% \mathrm{a}$ & $0.50 \% \mathrm{a}$ & $0.35 \% \mathrm{c}$ & $13.01 \% \mathrm{a}$ & $13.97 \%$ a \\
\hline $15 \mathrm{Krad}$ & $42 \mathrm{a}$ & $35.06 \mathrm{~b}$ & $33.8 \mathrm{bc}$ & $39.4 \mathrm{a}$ & $1.09 \% \mathrm{c}$ & $1.13 \% \mathrm{~b}$ & $0.31 \% \mathrm{c}$ & $0.39 \% \mathrm{~b}$ & $13.16 \% \mathrm{a}$ & $13.86 \% \mathrm{ab}$ \\
\hline $25 \mathrm{Krad}$ & $35.8 \mathrm{bc}$ & $28.92 \mathrm{c}$ & $33.7 \mathrm{bc}$ & $38.2 \mathrm{a}$ & $0.84 \% \mathrm{~d}$ & $1.17 \% \mathrm{~b}$ & $0.38 \% \mathrm{~b}$ & $0.68 \%$ a & $12.82 \% \mathrm{a}$ & $13.58 \% \mathrm{ab}$ \\
\hline $35 \mathrm{Krad}$ & $37 \mathrm{~b}$ & $28.13 \mathrm{~d}$ & $35.2 \mathrm{~b}$ & $33.3 \mathrm{~b}$ & $1.45 \% \mathrm{~b}$ & $1.35 \% \mathrm{a}$ & $0.28 \% \mathrm{~d}$ & $0.38 \%$ bc & $12.86 \% \mathrm{a}$ & $13.16 \% \mathrm{~b}$ \\
\hline $45 \mathrm{Krad}$ & $26 \mathrm{~d}$ & $19 \mathrm{e}$ & $44.6 \mathrm{a}$ & $30.5 \mathrm{c}$ & $1.45 \% \mathrm{~b}$ & $1.17 \% \mathrm{~b}$ & $0.49 \% \mathrm{a}$ & $0.35 \% \mathrm{c}$ & $12.84 \% \mathrm{a}$ & $13.69 \% \mathrm{ab}$ \\
\hline LSD $\alpha=0.05$ & 1.3944 & 0.7432 & 2.0103 & 1.7407 & 0.1427 & 0.073 & 0.0274 & 0.0396 & 0.5723 & 0.7208 \\
\hline
\end{tabular}

Data are represented as Mean $(\mathrm{n}=05)$. Means followed by different letter within the column are significantly different $(\mathrm{P}<0.05)$. (ANOVA followed by Tukey LSD test)

\section{Conclusion}

The present study concludes that gamma irradiation significantly affected various morphological parameters while biochemical attributes were nonsignificantly affected in M2 generation. The most significant dose was $15 \mathrm{Krad}$ as it improved various morphological and biochemical parameters while the most inhabitant dose was $45 \mathrm{Krad}$ due to its negative effect on various parameters in both verities. It is concluded that lower doses can be used for agricultural purposes to improve yield attributes of wheat.

\section{Authors' contributions}

Conceived and designed the experiment: WM Khan, Performed the experiment: S Ahmed, S Hussain \& SS Shah, Analyzed the data: WM Khan, N Umar \& S Ali, Contributed reagents/ materials/ analysis tools: MS Khan \& N Akhtar, Wrote the paper: S Ahmed \& WM Khan.

\section{References}

1. Muhammad A, Rehman M \& Zafar $Y$ (2005). DNA finger printing studies of some wheat (Triticum aestivum L.) genotypes using Random Amplified Polymorphic DNA (RAPD) analysis. Pakistan Journal of Botany 37(2): 271277.

2. Ashraf M, Cheema AA, Rashid M \& Qamar Z (2003). Effect of gamma rays on M1 generation in Basmati rice.
Pakistan Journal of Botany 35(5): 791795.

3. Emrani A, Razavi A \& Rahimi MF (2012). Assessment of gamma ray irradiation effects on germination and some morphological characters in two corn cultivars. International Journal of Agriculture and Crop Sciences 5: 12351244.

4. Ghirija M \& Dhanavel D (2009). Mutagenic effectiveness and efficiency of gamma rays, ethyl methane sulphonate and their combined treatments in cowpea (Vigna unguiculata L. Walp). International Journal of Molecular Sciences 4: 68-75.

5. Khatri A, Khan IA, Siddiqui MA, Raza R \& Nizamani GS (2005). Evaluation of high yielding mutants of Brassica jancea cv. s-9 developed through gamma rays and EMS. Pakistan Journal of Botany 37(2): 279-284.

6. Shah TM, Ali I \& Rahman K (2001). Abasin-95 a new oil seed rape cultivar developed through induced mutations. Mutation Breeding Newsletter 45: 3-4.

7. Din R, Khan MM, Qasim M, Jehan S \& Khan MI (2003). Induced Mutability Studies in three Wheat (Triticum aestivum L.) varieties for some morphological and agronomic characteristics. Asian Journal of Plant Sciences 2(17): 1179-1182. 
8. Ilyas S \& Naz S (2014). Effect of gamma irradiation on morphological characteristics and isolation of Curcuminoids and Oleoresins of Curcuma longa L. Journal of Animal and Plant Sciences 24(5): 1396-1404.

9. Ahmad S \& Qureshi S (1992). Comparative study of two cultivars of Zea mays L. after seed irradiation. Sarhad Journal of Agriculture 8: 441447.

10. Aynehband A \& Afsharinafar K (2012). Effect of gamma irradiation on germination characters of Amaranth seeds. European Journal of Experimental Biology 2(4): 995-999.

11. Songsri P, Suriharn B, Sanitchon J, Srisawangwong S \& Kesmala T (2011). Effect of gamma radiation on germination and growth characterstics of physic nut (Jatropha curcas L.). International Journal of Biological Sciences 11(3): 268- 274.

12. Marcu D, Grigore D, Cosma C \& Cristea V (2013). Gamma radiation effects on seed germination, growth and pigment content, and ESR study of induced free radicals in maize (Zea mays). Journal of Biological Physics 39(4): 625-634.

13. Singh NK \& Balyan HS (2009). Induced mutations in bread wheat (Triticum aetivum L.) CV. 'Kharchia $65^{\prime}$ for reduced plant height and improved grain quality traits. Advance Biology Research 3(5-6): 215-221

14. Irfaq M \& Nawab K (2001). Effects of gamma irradiation on some morphological characteristics of three wheat cultivars. International Journal of Biological Sciences 1(10): 935-937.

15. Khah M \& Verma ARC (2000). Assessment of the effects of gamma radiations on various morphological and agronomic traits of common wheat (Triticum aestivum L.) var. WH-147.
European Journal of Experimental Biology 5(7): 6-11.

16. Naik SI \& Nadaf HL (1997b). Induced variability for quantitative characters in groundnut (Arachis hypogaea L.). Journal of Crop Improvement 24(2): 226-230.

17. Laghary KA, Sial MA \& Afzal MA (2012). Effect of high temperature stress on grain yield and yield components of wheat (Triticum aestivum L.) Science Technology and Development 31(2): 8390.

18. Khan AS \& Malik MA (1999). Effect of gamma irradiation on morphological characters of three wheat varieties. Pakistan Journal of Biological Sciences 2(3): 903-905.

19. Khan M, Din MR, Qasim M, Jehan S \& Iqbal MM (2003). Induced mutability studies for yield and yield related characters in three wheat (Triticum aestivum L.) varieties. Asian J Plant Sci 2(17-24): 1183-1187.

20. Animasaun DA, Morakinyo JA \& Mustapha OT (2014). Assessment of the effects of gamma irradiation on the growth and yield of Digitaria exilis (Haller). Journal of Applied Biosciences 75: 6164-6172.

21. Mohamed WM \& El-Shimi I (2014). The effect of gamma rays on the pharmaceutical products of essential oils for peppermint (Mentha piperita L.). International Journal of Farming and Allied Sciences 3(8): 884-894.

22. Albokari M (2014). Induction of mutants in durum wheat (Triticum durum desf cv. samra) using gamma irradiation. Pakistan Journal of Botany 46(1): 317-324.

23. Irfaq M \& Nawab K (2003). A study determines the proper dose of gamma radiation for inducing beneficial genetic variability in bread wheat (Triticum 
aestivum L.). Asian Journal of Plant Sciences 2(13): 999-1003.

24. Bamidele OP \& Akanbi C (2013). Effect of gamma irradiation on physicochemical properties of stored pigeon pea (Cajanus cajan) flour. Food Science Nutrition 1(5): 377-383.

25. Bhat R, Sridhar KR, Alias AK, Young CC \& Arun BA (2009). Influence of gamma radiation on the nutritional and functional qualities of lotus seed flour. Journal of Agricultural and Food Chemistry 57: 9524-9531.
26. Rao VS, Shrirangarajan AN, Kamat AS, Adhikari HR \& Nair PM (1994). Studies on extension of shelf-life of rawa by gamma irradiation. Journal of Food Science and Technology 3(1): 311-315.

27. Rahimi MM \& Bahrani A (2011). Influence of gamma radiation on some physiological characteristics and grain protein in wheat (Triticum aestivum). World Applied Sciences Journal 15(5): 654-659. 